\title{
Science Academies' Refresher Course on Experimental Biology: Orthodox to Modern
}

\author{
07- 19, November 2016 \\ PG and Research Department of Botany, St.Joseph's College (Autonomous) \\ Tiruchirappalli, Tamil Nadu 620002
}

\author{
Sponsored by Indian Academy of Sciences, Bengaluru \\ Indian National Science Academy, New Delhi \\ The National Academy of Sciences, India, Allahabad
}

\begin{abstract}
A refresher course on 'Experimental Biology: Orthodox to Modern' will be held at PG and Research Department of Botany, St.Joseph's College, Tiruchirappalli, Tamil Nadu for two weeks from 07 November to 19 November 2016. The objective of this course is to improvise on teaching methodologies and also get familiar with basics to advanced laboratory techniques in life sciences including cell and molecular biology. The resource persons will be eminent scientists working in these fields who are distinguished Fellows of the National Science Academies. The participants of the refresher course will have hands-on experience with all of the advanced facilities available in the SJC.
\end{abstract}

Applications are invited from teachers with experience in teaching postgraduate courses in Life Sciences. Applications from highly motivated Research Scholars will also be considered. Maximum 35 applications will be considered. Teachers who wish to participate in the refresher course may apply through proper channel with the following details: name, date of birth, gender, e-mail, official and residential addresses, telephone numbers, academic qualifications, courses taught, affiliation, positions held and tenure. It is also essential to submit a brief statement (between 250 and 500 words) as to why they think the Course will help to improve their classroom teaching of Life Science. There will be NO application fee/registration fee.

Applications should be submitted ONLINE by clicking the following link:

http://web-japps.ias.ac.in:8080/Refreshcourse/REBOM.jsp

A print copy of the application must also be sent by speed post forwarded by the Head of the institution. It should reach Dr. T.Francis Xavier, Coordinator Refresher Course on 'Experimental Biology: Orthodox to Modern', PG and Research Department of Botany St.Joseph's College, Tiruchirappalli - 620 002, Tamil Nadu before October 2016. Out station candidates will be provided local hospitality and round trip bus/train (three- tier AC) fare by the shortest route as per the guidelines of Academy.

Course Director: Dr.D.J.Bagyaraj, INSA Honorary Scientist, Centre for Natural Biological Resources and Community Development (CNBRCD), Bangalore Course Coordinator: Dr T Francis Xavier, Assistant Professor, PG and Research Department of Botany St.Joseph's College, Tiruchirappalli - 620 002, Tamil Nadu (E.mail: mycofrancis@yahoo.co.in ; Mobile: +91 - 9944073773).

Last date for receipt of applications: 05 October 2016

Selected participants will be informed on 10 October 2016 